\title{
Partial characterization of two ruminal bacteriophages with similar restriction patterns and different capsids morphology
}

\begin{abstract}
Two bacteriophages (F5 and F6) were isolated from lysogenic Streptococcus bovis strains 46/2 and 59/2, respectively, after spontaneous induction. Both bacteriophages produced clear and small plaques (0.1- $0.2 \mathrm{~mm}$ in diameter) on two host Streptococcus bovis strains (47/3 and 4/1) out of 12 tested. After UV-light induction, clear plaques of $1.0-1.2 \mathrm{~mm}$ in diameter were observed. Both bacteriophages were relatively resistant to chloroform, however, their survival in sterilised rumen fluid was not long because their complete inactivation was observed after 18 hours of cultivation in sterilised rumen fluid. Transmission electron microscopy showed great differences in the morphology of particles of these two bacteriophages. The F5 phage had an elongated slightly angular head, of a mean length of $94 \mathrm{~nm}$ and width of $50 \mathrm{~nm}$, as well as a $180 \mathrm{~nm}$ long and 10-15 nm wide noncontractile flexible tail without a sheath. The bacteriophage F6 had an isometric head of icosahedral shape, $43 \mathrm{~nm}$ in diameter, and its noncontractile flexible tail without sheath was about 180-200 nm long and 10-12 nm wide. According to Ackermann`s classification both phages belong to Siphoviridae. The genome sizes of both phages, determined by summing the molecular sizes of fragments generated by digestions with EcoRI, PstI, BglII and XbaI, were similar (about 41-43 kb). Restriction analysis of the genomes of these 2 bacteriophages by 8 restriction enzymes showed that SalI, BamHI and BspRI did not cleave the DNAs of these phages. Cleavage of the DNAs with the other five restriction enzymes showed a similar restriction pattern, however, with small differences. It is a curiosity to find two bacteriophages with the same genome size and relatively similar DNA restriction patterns having a different morphology of their capsids.
\end{abstract}

Key Words: rumen, bacteriophages, Streptococcus bovis

\section{Zusammenfassung}

Titel der Arbeit: Partielle Charakterisierung von zwei Bakteriophagen im Pansen mit ähnlichen Restriktionsmustern und unterschiedlicher Morphologie der Proteinhülle

Aus den lysogenen Streptococcus bovis Stämmen 46/2 und 59/2 wurden nach spontaner Induktion zwei Bakteriophagen (F5 und F6) isoliert. Beide Bakteriophagen produzierten klare und kleine Plaques (Durchschnitt 0,1$0,2 \mathrm{~mm}$ ) auf zwei aus insgesamt 12 untersuchten Streptococcus bovis Wirtsstämmen (47/3 und 4/1). Nach der Induktion mit UV-Licht wurden klare Plaques von 1,0 - 1,2 mm Durchmesser beobachtet. Beide Bakteriophagen waren relativ resistent gegenüber Chloroform, jedoch war ihre Überlebensrate in sterilisierter Pansenflüssigkeit nicht groß, da ihre vollständige Inaktivierung nach 18-stündiger Kultivierung in sterilisierter Pansenflüssigkeit beobachtet wurde. Die Transmissionselektronenmikroskopie zeigte deutliche Unterschiede in der Partikelmorphologie dieser beiden Bakteriophagen. Der F5 Bakteriophage besaß einen länglichen und etwas kantigen Kopf mit einer Durchschnittsgröße von $94 \mathrm{~nm}$ Länge und $50 \mathrm{~nm}$ Breite und weiterhin einen $180 \mathrm{~nm}$ langen und 10-15 nm dicken, nicht-kontraktilen flexiblen Schwanz ohne Scheide. Der F6 Bakteriophage hatte einen isodiametrischen Kopf in Form eines Ikosaeders mit einem Durchmesser von $43 \mathrm{~nm}$; sein nicht-kontraktiler flexibler Schwanz ohne Scheide war ungefähr 180 - $200 \mathrm{~nm}$ lang und $10-12 \mathrm{~nm}$ breit. Beide Phagen gehören nach Ackermann's Klassifizierung zu den Siphoviridae. Die Genomgrößen beider Phagen, die bestimmt wurden durch Addition der molekularen Größen von Fragmenten nach Verdau mit EcoRI, PstI, BglII und XbaI, waren ähnlich (ungefähr $41-43 \mathrm{~kb}$ ). Die Restriktionsanalyse der Genome dieser beiden Bakteriophagen mit 8 Restriktionsenzymen ergab, dass SalI, BamHI und BspRI die DNA dieser Phagen nicht schnitten. Das Zerschneiden der DNAs mit den anderen 5 Restriktionsenzymen ergab (mit kleinen Unterschieden) ähnliche Restriktionsmuster. Es ist ungewöhnlich, dass zwei Bakteriophagen die gleichen Genomgrößen und vergleichbare DNA-Restriktionsmuster aber eine unterschiedliche Morphologie ihrer Proteinhülle aufweisen. 


\section{Introduction}

The rumen ecosystem comprises a complex of dense microbial communities of bacteria, archaea, protozoa, fungi and bacteriophages (KLIEVE et al., 2004). Therefore, a large and diverse population of bacteriophages is present in the rumens of several ruminants (PAYNTER et al., 1969; TARAKANOV, 1971). Phages probably play an important role in the population dynamics of ruminal bacteria resulting in their lysis (KLIEVE and SWAIN, 1993) as well as in modifying bacterial phenotypes by the selection of phageresistant bacteria (KLIEVE and BAUCHOP, 1991). However, phages lytic to ruminal bacteria were isolated from the rumen contents in low frequencies (IVERSON and MILLIS, 1976a; TARAKANOV, 1976). It suggests that the majority of phages in the rumen may exist in harmony with their hosts in a state of lysogeny or pseudolysogeny (KLIEVE and BAUCHOP, 1988) or the susceptible hosts may not yet have been found. The lysogenic cultures releasing temperate bacteriophages were previously isolated from ruminal contents, however, the information of IVERSON and MILLIS (1976b) about 4\% of lysogenic among Streptococcus bovis strains tested was at variance with the previous findings of TARAKANOV (1974), who reported that $47,9 \%$ of his ovine and $55,5 \%$ of his bovine $S$. bovis strains were lysogenic as well as with the published results of KLIEVE et al. (1989) who obtained 23.7\% lysogenic ruminal isolates. Streptococcus bovis bacteriophages previously described in our papers (ŠTYRIAK et al., 1989; ŠTYRIAK et al., 1994) were isolated from the ruminal fluid samples as the lytic phages. To find a lysogenic strain, 12 Streptococcus bovis strains of our collection were tested for the spontaneous release of phage particles, however, they were treated also by UV-light. Both our bacteriophages (F5 and F6) in this paper described were spontaneously released by their host strains (46/2 and 59/2, respectively). Their lytic activity against $S$. bovis strains was tested not only in medium, however, also on rumen epithelium primoculture because of the previous observations that F6 bacteriophage significantly decreased the number of adherent bacteria (ŠTYRIAK et al., 1991).

The work presented here was directed to the comparison of some characteristics of these two ruminal bacteriophages.

\section{Material and methods}

\section{Isolation and propagation of bacteriophages}

Phages F5 and F6 were isolated from lysogenic Streptococcus bovis strains 46/2 and 59/2, respectively. Both bacteriophages were propagated on Streptococcus bovis 47/3 strain at $37^{\circ} \mathrm{C}$ using Nutrient broth No.2 (Imuna Šarišské Michal'any). Lysates were clarified by centrifugation (5000g for $25 \mathrm{~min}$ ) and titrated. Phage titres were usually examined by the double agar layer method on Nutrient agar No.2 (Imuna) covered with $0.7 \%$ top agar having been inoculated with both Streptococcus bovis $47 / 3$ strain and diluted phage lysate. Bacteriophages were purified by three reisolations of single plaques.

\section{Determination of host specificity of bacteriophages}

The host range of each phage was determined by spot tests of phage lysates: $20 \mu \mathrm{l}$ of lysate was spotted onto Nutrient agar No.2 plates previously poured in a double layer, the $0.7 \%$ top agar layer having been inoculated with cultures of the strain tested. 


\section{Electron microscopy of phages}

For electron microscopy, phage lysates were centrifuged at $20000 \mathrm{~g}$ for $120 \mathrm{~min}$ using a UP-65 ultracentrifuge, and sediments were washed twice in ammonium acetate (0.1M; $\mathrm{pH}$ 7.0). The sediments were subsequently deposited on copper grids Tesla 300 Mesh with carbon-coated Formvar films, negatively stained with potassium phosphotungstate or phosphotungstic acid (both 2\%; pH 7.2) and examined in a transmission electron microscope Jeol-JEM 1200 at an accelerating voltage of $80 \mathrm{kV}$. At least 50 particles were measured per individual phage species.

\section{Isolation and restriction analysis of phage DNAs}

The phages were concentrated by precipitating lysates with polyethylene glycol (PEG) 6000 (8\% wt/vol) as described by YAMAMOTO et al. (1970). Phage DNAs were prepared by phenol-chloroform extraction followed by ethanol precipitation according to MANIATIS et al. (1982) as described earlier (ŠTYRIAK et al., 1994).

Both phage DNAs were digested with the same 8 restriction endonucleases (EcoRI, PstI, and BspRI obtained from ÚSOL Praha; SalI, BglII, XbaI, HindIII, and BamHI from Boehringer Mannheim) at $37^{\circ} \mathrm{C}$ in the appropriate buffers according to MANIATIS et al. (1982).

\section{Electrophoresis of phage DNAs}

DNA fragments were resolved by horizontal gel electrophoresis with $0.7 \%$ agarose in Tris-acetate buffer at a constant voltage of $2.5 \mathrm{~V} / \mathrm{cm}$ for $10-12$ hours. In order to visualize the DNA bands, gels were stained with ethidium bromide $(1 \mu \mathrm{g} / \mathrm{ml})$ and subsequently illuminated with long-wavelength UV light on a transilluminator.

\section{Results}

\section{Bacteriophages isolation, plaque morphology and host ranges}

Both F5 and F6 bacteriophages were isolated from lysogenic Streptococcus bovis strains (F5 phage from 46/2 strain and F6 phage from 59/2 strain) after spontaneous induction. Both bacteriophages have similar narrow host ranges. The plaques produced by both these phages on two host Streptococcus bovis strains (47/3 and 4/1) out of 12 tested were clear and small (0.1-0.2 mm in diameter). Occasionally were observed greater turbid plaques (0.9-1.2 mm in diameter), however, any lysogenic colonies were not isolated. After UV-light induction were observed clear plaques of 1.0-1.2 mm in diameter. It is interesting to note that the both $46 / 2$ and 59/2 S.bovis strains were resistant against both F5 and F6 bacteriophages. Therefore, superinfection of these strains was not observed.

\section{Sensitivity of phages to chloroform and to rumen fluid}

Both F5 and F6 bacteriophages are relatively resistant to chloroform (their titer decreased slightly after one month of maintenance at $4^{\circ} \mathrm{C}$ in medium including chloroform), however, their survival in sterilised rumen fluid is significantly lower than survival of F4 bacteriophage earlier characterized (ŠTYRIAK et al., 1994). The complete inactivation of these two bacteriophages was observed after 18 hours of cultivation in sterilised rumen fluid. Therefore, it seems that F5 and F6 bacteriophages are not able to exist in rumen fluid for a longer time.

\section{Electron microscopy}

Transmission electron microscopy showed great differences in particles morphology of 
these two bacteriophages. F5 phage had elongated slightly angular head (Figure 1) similar to Pseudomonas aeruginosa 1214P phage described by ACKERMANN et al. (1988).

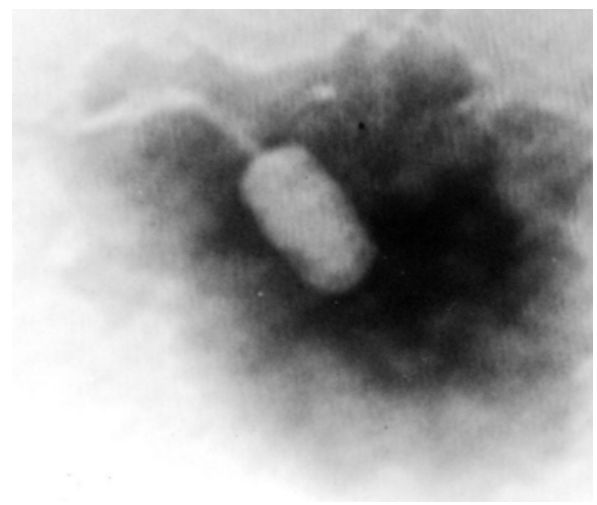

Fig. 1: F5 bacteriophage particle, enlarged 75000 x (F5-Bakteriophage, 75000-fach vergrößert)

Its head is in average $94 \mathrm{~nm}$ long and $50 \mathrm{~nm}$ wide. The head feature is apparent especially on some empty phage particles, however, a slight angular morphology is shown also by the other F5 particles. Phage heads were designated as empty on the basis of appearance, as is normal practice (BRADLEY, 1967). This phage has $180 \mathrm{~nm}$ long and 10-15 nm wide noncontractile flexible tail without sheath. No collar or base plate appeared to be present. This phage was classified on the basis of its morphology according to the scheme of BRADLEY (1967) and was assigned to group B. It belongs to Siphoviridae according to Ackermann`s classification (ACKERMANN, 1992).

Bacteriophage F6 (Fig. 2) had isometric head of icosahedral shape $43 \mathrm{~nm}$ in diameter, as evidenced by the observation of capsids with hexagonal outlines. A large but variable proportion of the observed virions had empty and also detached heads (Fig. 3).
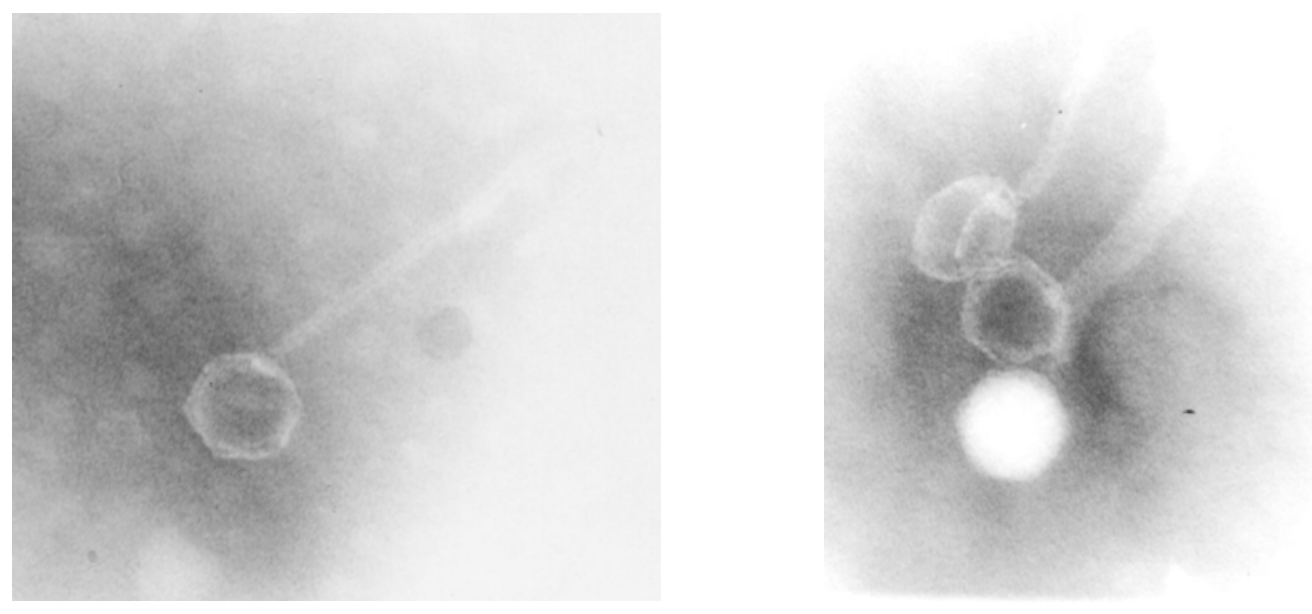

Fig. 2 (left) and Fig. 3 (right): F6 bacteriophage particle, enlarged $10^{5}$ x (F5-Bakteriophage, $10^{5}$-fach vergrößert)

It is similar to Streptococcus salivarius subsp. thermophilus phage $\varphi 81$ described by PREVOTS et al. (1989). Bacteriophage particles with empty heads were found also in rumen contents (KLIEVE et al., 1989; KLIEVE et al., 2004), however, among our rumen 
bacteriophage isolates were many empty phage heads detected only in native lysates of F6 bacteriophage. In case of agreement with the opinion of TARAKANOV (1971) that empty phage heads document running infection process, it could be considered that we reached the F6 phage population in advanced phase of this process in comparison with the other bacteriophages investigated. Its noncontractile flexible tail without sheath is about 180-200 nm long and 10-12 nm wide. It is transversely striated like to Streptococcus salivarius subsp. thermophilus phage $\varphi 81$ described by PREVOTS et al. (1989).

This phage was classified on the basis of the scheme of BRADLEY (1967) to group A. It belongs also to Siphoviridae according to Ackermann`s classification (ACKERMANN, 1992).

\section{Restriction analysis of phage DNAs}

Genome sizes of both phages, determined by summing the molecular sizes of fragments generated digestions with EcoRI, PstI, BglII and XbaI, were similar (about 41-43 kb). Figure 4 shows the restriction analysis of genomes of these 2 bacteriophages by 8 restriction enzymes.

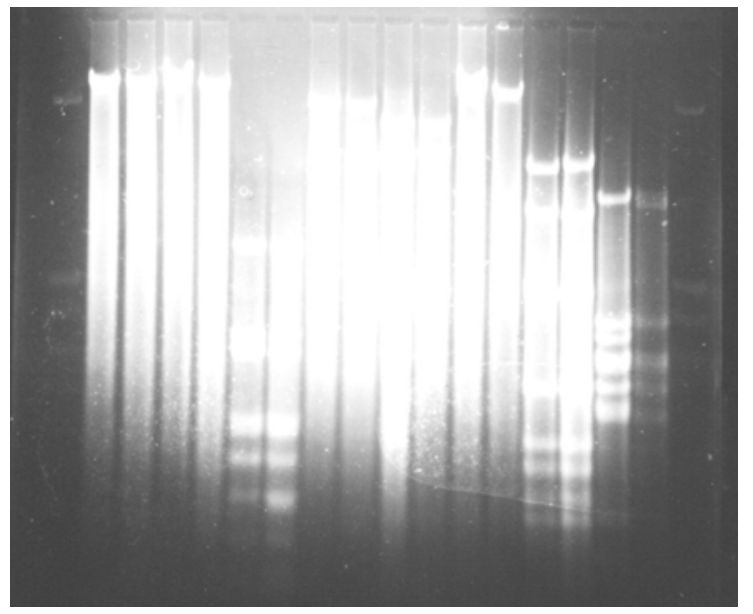

Fig. 4: Restriction analysis of genomes of F5 and F6 bacteriophages by 8 enzymes (Restriktionsanalyse der Genome der F5- und F6-Bakteriophagen durch 8 Enzyme)

Lanes 1 a 18 (Sevac I), 2 (F5/EcoR I), 3 (F6/EcoR I), 4 (F5/Pst I), 5 (F6/Pst I),

6 (F5/Sal I), 7 (F6/Sal I), 8 (F5/Bgl II), 9 (F6/Bgl II), 10 (F5/Xba I), 11 (F6/Xba I),

12 (F5/Hind III), 13 (F6/Hind III), 14 (F5/BamH I); 15 (F6/BamH I), 16 (F5/BspR I),

17 (F6/BspR I)

Restriction endonucleases SalI, BamHI and BspRI did not cleave DNAs of these phages. The cleavage of DNAs with the other five restriction enzymes showed the similar restriction pattern, however, two differences were found. A greater difference was observed after cleavage with EcoRI when three smaller fragments $(3,81 ; 3,32 \mathrm{a} \mathrm{2,76} \mathrm{kb)}$ were found in F6 phage DNA instead of one grater B fragment $(8,74 \mathrm{~kb})$ in F5 phage DNA. Except this, some small fragments in this lane were not detected on $0.7 \%$ agarose gel. However, a difference was observed also after cleavage with Hind III when in F5 phage DNA was not found $3.56 \mathrm{~kb}$ fragment but there was detected in addition $1.73 \mathrm{~kb}$ fragment in comparison with F6 phage DNA.

It is also very interesting to note that two bacteriophages with the same genome sizes and relatively similar DNA restriction patterns have different morphology of their capsids. According to our best knowledge, it is really a curiosity. 


\section{Discussion}

TARAKANOV (1974) endeavoured to confirm the assumption that an important source of bacteriophages in rumen are the lysogenic bacterial cultures. His experiments confirmed that lysogeny is widely distributed among the cultures of Streptococcus bovis inhabiting the rumen of ruminant animals and that bacteriophages are released from their host bacteria as spontaneously as after induction by UV-light or by chloroform.

On the other hand, according to IVERSON and MILLIS (1976a) the lysogenic cultures are not a significant source of bacteriophages in rumen.

On the basis of our opinion concerning isolation of ruminal bacteriophages (especially Streptococcus bovis bacteriophages), we incline to view of Tarakanov that lysogenic strains could be an important source of bacteriophages in rumen of ruminants despite the fact that among our S. bovis isolates only two (Streptococcus bovis 46/2 a 59/2) were appeared as lysogenic because of bacteriophage releasing. As described above, the bacteriophage releasing was observed after spontaneous induction of these strains. These phages formed originally small hazy plaques. However, UV-light induction accelerated this releasing process as confirmed by greater clear plaques on host $S$. bovis strains after UV-light induction. The other $S$. bovis strains released not any bacteriophages as spontaneously as after UV-light induction.

Ruminal bacteriophages may have very narrow host ranges, and susceptible hosts may not yet have been found (KLIEVE and BAUCHOP, 1988). According to KLIEVE et al. (1989) phages lytic to ruminal bacteria are not common in the rumen and suggests that the phages observed directly in ruminal contents may originate from lysogenic or pseudolysogenic associations between bacteriophages and ruminal bacteria.

Detected numbers of ruminal bacteria harboring prophage should be regarded as a minimum, as it is well known that not all lysogens are inducible. In addition, of the inducible bacteria present, some may not be induced by a specific induction procedure. Therefore, it appears likely that the proportion of bacterial isolates from the rumen that harbor temperate phages could be higher than were really detected (KLIEVE et al., 1989).

In the rumen ecosystem, the selection of phage-resistant bacteria with altered growth characteristics may be a factor in modifying bacterial phenotypes, and thus increasing variability among bacteria which are closely related genetically (KLIEVE and BAUCHOP, 1991). A new Streptococcus bovis phage ( $\varphi$ Sb01) was isolated during the study of lytic bacteriophages in rumen contents. This phage after infection of parents culture of Streptococcus bovis 2B strain on which was isolated and propagated allowed a distinct growth of phage-resistant colonies of this strain, however, with a distinct different phenotype. Each infection of original parent strain S.bovis 2B by $\varphi S b 01$ phage resulted to growth of culture in distinct contrast to that of the parent host strain. Similar secondary overgrowth of culture with altered phenotype was observed also after infection of Bacteroides ruminicola subsp. brevis AR 20 strain by $\varphi$ Brb01 a $\varphi$ Brb02 phages (KLIEVE et al., 1991). This suggests that bacteriophages in the rumen ecosystem may be continually altering the phenotype of bacterial populations, thus increasing the diversity among organisms that are closely related genetically (KLIEVE and BAUCHOP, 1991).

Both F5 and F6 bacteriophages are characteristic by linear DNA as well as by great similarity of their restriction profiles despite fact that they have different morphology and were isolated from different lysogenic strains. It would be useful to ascertain, e.g. by means of hybridization, whether these bacteriophages are found in the chromosoms of 
bacterial strains in the form of prophages and therefore they are temperate bacteriophages, or extrachromosomally as described in the "phage-carrying" strain Leuconostoc oenos 58N (ARENDT et al., 1990) or phage J7W-1 of Bacillus thuringiensis (KANDA et al., 1989). Bacteriophages found in bacterial strains extrachromosomally are often unstable, also in cases when they integrate into plasmid of their host strain as described in the case of phage J7W-1 of Bacillus thuringiensis (KANDA et al., 1989).

\section{Acknowledgements}

This study was supported by the VEGA Grant No 2/2043/22. Authors would like to thank to Mrs. G. Gréserová for translation of English summary to German language as well as for language correction of whole manuscript text.

\section{ACKERMANN, H.W.:}

\section{References}

Frequency of morphological phage descriptions. Arch.Virol., 124 (1992), 201-209

ACKERMANN, H.W.; CARTIER, C.; SLOPEK, S.; VIEU, J.F.:

Morphology of Pseudomonas aeruginosa typing phages of the Lindberg set. Ann. Microbiol. (Paris), 139 (1988), 389-404

ARENDT, E.K.; NEVE, H.; HAMMES, W.P.:

Characterization of phage isolates from a phage -carrying culture of Leuconostoc oenos 58N. Appl. Microbiol. Biotechnol., 34 (1990), 220-224

BRADLEY, D.E.: Ultrastructure of bacteriophages and bacteriocins. Bacteriol. Rev., 31 (1967), 230-314

IVERSON, W.G.; MILLIS, N.F.:

Characterization of Streptococcus bovis bacteriophages. Can. J. Microbiol., 22 (1976a), 847-852

IVERSON, W.G.; MILLIS, N.F.: Lysogeny in Streptococcus bovis. Can. J. Microbiol., 22 (1976b), 853-857

KANDA, K.; TAN, Y.; AIZAWA, K.:

A novel phage genome integrated into a plasmid in Bacillus thuringiensis strain AF101. J. Gen. Microbiol., 135 (1989), 3035-3041

KLIEVE, A.V.; BAUCHOP, T.:

Morphological diversity of ruminal bacteriophages from sheep and cattle. Appl. Environ. Microbiol., 54, (1988), 1637-1641

KLIEVE, A.V.; HUDMAN, J.F.; BAUCHOP, T.:

Inducible bacteriophages from ruminal bacteria. Appl. Environ. Microbiol., 55 (1989), 1630-1634

KLIEVE, A.V.; BAUCHOP, T.:

Phage resistance and altered growth habit in a strain of Streptococcus bovis. FEMS Microbiol.Lett., 80, (1991), 155-160

KLIEVE, A.V.; GREGG, K.; BAUCHOP, T.:

Isolation and characterization of lytic phages from Bacteroides ruminicola ss brevis. Curr. Microbiol., 23 (1991), 183-187

KLIEVE, A.V.; SWAIN, R.A.:

Estimation of ruminal bacteriophage numbers by pulsed-field gel electrophoresis and laser densitometry. Appl. Environ. Microbiol., 59 (1993), 2299-2303

KLIEVE, A.V.; BAIN, P.A.; YOKOYAMA, M.T.; OUWERKERK, D.; FORSTER, R.J.; TURNER, A.F.: Bacteriophages that infect the cellulolytic ruminal bacterium Ruminococcus albus AR67. Lett. Appl. Microbiol., 38 (2004), 333-338

MANIATIS, T.; FRITSCH, E.F.; SAMBROOK, J.J.:

Molecular cloning laboratory manual. Cold Spring Harbor Laboratory, Cold Spring Harbor, New York, 1982

PAYNTER, M.J.B.; EWERT, D.L.; CHALUPA, W.:

Some morphological types of bacteriophages in bovine rumen contents. Appl. Environ. Microbiol., 18 (1969), 942-943

PREVOTS, F.; RELANO, P.; MATA, M.; RITZENTHALER, P.: Close relationship of virulent bacteriophages of Streptococcus salivarius subsp thermophilus at both the protein and the DNA level. J. Gen. Microbiol., 135, (1989), 3337-3344 
ŠTYRIAK, I.; KMEŤ, V.; ŠPANOVÁ, A.:

Isolation and characterization of two rumen Streptococcus bovis bacteriophages. Microbiologica, 12 (1989), 317-322

ŠTYRIAK, I.; GÁLFI, P.; KMEŤ, V.:

Preliminary observations of interaction between bacteriophages and Streptococcus bovis bacteria on rumen epithelial primoculture. Vet. Microbiol., 29 (1991), 281-287

ŠTYRIAK, I.; ŠPANOVÁ, A.; MONTAGOVÁ, H.; KMEŤ, V.:

Isolation and characterization of a new ruminal bacteriophage lytic to Streptococcus bovis. Curr. Microbiol., 28 (1994), 355-358

TARAKANOV, B.V.:

Bacteriophages of cattle rumen. Mikrobiologija, 40 (1971), 544-550 (in Russian with English abstract)

TARAKANOV, B.V.:

Lysogenic cultures of Streptococcus bovis isolated from rumen of cattle and sheep. Mikrobiologija, 43 (1974), 375-377 (in Russian with English abstract)

TARAKANOV, B.V.:

Biological characteristics of bacteriophages for Streptococcus bovis isolated from lysogenic cultures and ovine rumen. Mikrobiologija, 45 (1976), 695-700 (in Russian with English abstract)

YAMAMOTO, K.R.; ALBERTS, B.M.; BENZINGER, L.; LAWHORNE, L.; TREIBER, G.:

Rapid bacteriophage sedimentation in the presence of polyethylene glycol and its application to large-scale virus purification. Virology, 40 (1970), 734-744

Received: 2004-06-18

Accepted: 2005-07-29

Author's addresses

Dr. IGOR ŠTYRIAK, PhD.

Institute of Animal Physiology,

Slovak Academy of Sciences

Šoltésovej 4-6

04001 Košice, Slovakia

\section{Dr. ALENA ŠPANOVÁ}

Masaryk University Brno, Faculty of Science,

Kotlarska 2

61137 Brno, Czech Republic

Dr. RUDOLF ŽITŇAN*, DSc.

Research Institute of Animal Production Nitra,

Division Košice, Pri hati 10,

04001 Košice, Slovakia

E-mail: zitnan@uvm.sk

*Corresponding Author 